\title{
Thermodynamic Evaluation Of Solid Oxide Fuel Cells Converting Biogas Into Hydrogen And Electricity
}

\author{
R. Nogueira Nakashima*1, S. Oliveira Junior ${ }^{2}$ \\ University of São Paulo, Av. Prof. Mello Moraes, 2231 \\ 05508-900 São Paulo, Brazil \\ E-mail: ${ }^{1}$ rafaelnnakashima@usp.br, ${ }^{2}$ soj@usp.br
}

Received 10 February 2021, Revised 3 March 2021, Re-revised 11 April 2021, Accepted 3 May 2021

\begin{abstract}
Although biogas has many qualities as a source of renewable and distributed energy, most full-scale applications are large facilities due to the lack of efficient small-scale systems. In this context, solid oxide fuel cells (SOFC) have been promoted as an alternative to convert biogas into electricity and heat with high efficiency. However, few studies have considered the use of the anode exhaust gas to co-produce green hydrogen together with electricity and heat, which could increase the performance and profitability of these systems. Thus, since there is a lack of studies focusing on these systems, this research proposes a new approach to model SOFC with direct internal reforming to produce power, hydrogen and heat. The results indicate that the proposed system is capable of reaching exergy efficiencies between $57 \%$ and $69 \%$ depending on the methane content of biogas. Hydrogen separation reduces the amount of fuel that has to be burned, which leads to less destruction of exergy in multiple processes (e.g., mixers, burners and heat exchangers). However, this design change also diminishes the amount of heat delivered by the system (-82\% compared with conventional cogeneration), which may negatively affect the energy integration with anaerobic digestion. In addition, major performance improvements can be achieved by optimizing the hydrogen recovery of the pressure swing adsorption and the SOFC operating temperature.
\end{abstract}

\section{Keywords: Biogas; solid oxide fuel cell; hydrogen; exergy analysis.}

\section{Introduction}

Biogas is an alternative fuel primarily consisted of methane and carbon dioxide that can be produced from renewable sources of energy, such as organic residues and energy crops. The main competitive advantage of biogas is the lower $\mathrm{CO}_{2}$ emissions in its production and usage compared with fossil fuels (e.g., natural gas and diesel fuel). However, the limited efficiency of conventional technologies for power conversion severely restricts the economic viability of biogas plants in general. A promising alternative is to design systems using fuel cells to directly convert biogas into electricity, since this process can be very efficient at small scales [1] and adapted to produce hydrogen as a byproduct [2]. The production of electricity, hydrogen and heat may increase the efficiency of biogas conversion and provide an additional source of revenue [3], while increasing the sustainability of hydrogen production and fuel cell technology.

Since fuel cell systems can be complex and expensive, the effect of different design choices has been the subject of discussion in many studies. In general, these studies have focused mainly on systems that work with natural gas. For instance, Palazzi, et al. [4] proposed a methodology to optimize solid oxide fuel cell (SOFC) systems using the principles of energy integration combined with evolutionary algorithms. They observed that an optimized design for a SOFC system is able to achieve energy efficiencies between $34 \%$ and $44 \%$. Becker, et al. [2] indicated that a conventional SOFC system could attain higher energy efficiencies (83.5-86.1\%) by including a separation step to export hydrogen as a byproduct. More recently, Pérez-
Fortes, et al. [5] reported energy efficiencies as high as $81.4 \%$ for a SOFC system co-producing hydrogen, electricity and heat under different operating conditions. It is important to highlight that the efficiency values from the aforementioned studies [2, 4, 5] are calculated based on energy. Therefore, they do not take into account the limits derived from the second law of thermodynamics.

The utilization of biogas as a fuel imposes some additional constraints for the design of SOFC systems due to the presence of contaminants and carbon dioxide. For instance, Van Herle, et al. [6] examined different technologies for biogas reforming and operating variables in order to estimate their impact on the system efficiency. Curletti, et al. [7] reported an optimization study including hybrid systems of SOFC combined with gas turbines and carbon capture for large power generation applications. More recently, MosayebNezhad, et al. [8] extended the analysis of energy integration to include the energy demands of a wastewater treatment plant. Although there are examples of studies evaluating the usage of biogas in fuel cell systems, most mathematical models in use neglect variations of fuel concentration and temperature along the fuel cells. Furthermore, simulations validated for different mixtures of hydrogen, water and carbon dioxide are scarce, despite the high concentration of these components in the reformed biogas. These factors can significantly impact the performance of high temperature fuel cells [9]. In addition, the inclusion of a hydrogen separation step in SOFC systems that work with biogas has rarely been discussed in detail. 
Thus, the operation with biogas creates new problems which require the development of a more detailed model of SOFCs to analyze the performance of these systems. In order to be suitable for mathematical optimization, the methods employed should take into consideration the tradeoffs between computational time and results accuracy. In this context, this research aims to provide a simplified method to simulate solid oxide fuel cells which could solve these aforementioned questions without compromising the possibility to perform optimization studies. Moreover, an analysis of the combined production of hydrogen and electricity using SOFCs that work with biogas and biomethane is developed using the proposed methods. This paper aims to provide the tools and analysis necessary to fulfill gaps in recent literature and discuss the intricate relationships between operational parameters and system efficiency.

\section{Process description}

The proposed system consists of a small centralized plant producing an average of $100 \mathrm{Nm}^{3} / \mathrm{h}$ of biogas [10], assuming that a gas processing unit removed the fuel impurities. Only a high temperature polishing step (adsorption using activated carbon) is included as a safeguard for the pre-reformer and fuel cells. Thus, a mixture as $60 \% \mathrm{CH}_{4}, 40 \% \mathrm{CO}_{2}$ and $5 \mathrm{ppm}$ of $\mathrm{H}_{2} \mathrm{~S}$ in molar basis is assumed as the constitution of biogas. This research focus on two scenarios: one that produces hydrogen and electricity; and another that bypass the hydrogen purification step and only generates electricity. In order to estimate the impact of methane concentration, the analysis compares the performance of biogas with biomethane (pure methane). The flow rate of biomethane is adjusted to 60 $\mathrm{Nm}^{3} / \mathrm{h}$ to maintain the same amount of energy input as in the biogas scenarios.

Figure 1 shows the system proposed to produce power and hydrogen combining a SOFC, operating close to atmospheric pressure (1.21 bar), and a pressure swing adsorption separation (PSA). The pre-reformer partially reforms biogas in an adiabatic process that achieves a conversion close to thermodynamic equilibrium [11], in order to increase the hydrogen concentration and improve the performance of fuel cells. The system of heat recovery and the anode recycle provide water for the reforming process. In order to prevent soot formation, a lower bound of 2 moles of water per mole of carbon at the pre-reformer inlet is imposed. Next, a heat exchanger preheats the reformed mixture before the conversion in the fuel cells.

The fuel cells convert hydrogen exergy into electricity while reforming methane and carbon monoxide along the anode. Their structure is planar, anode supported and arranged in stacks with co-current flow of fuel and air, a flow pattern that simplifies the numerical solution. The electrochemical oxidation and water gas shift reactions are able to provide energy for the steam reforming reaction. In order to simplify the numerical solution, the fuel cells operate with a constant current density $\left(0.3 \mathrm{~A} / \mathrm{cm}^{2}\right)$ and the efficiency of the power inverter is also constant $(\eta=95 \%)$. A high percent of theoretical air $\left(\lambda_{\text {cell }}=300 \%\right)$ controls the temperature of the fuel cell and avoid excessive voltage losses.

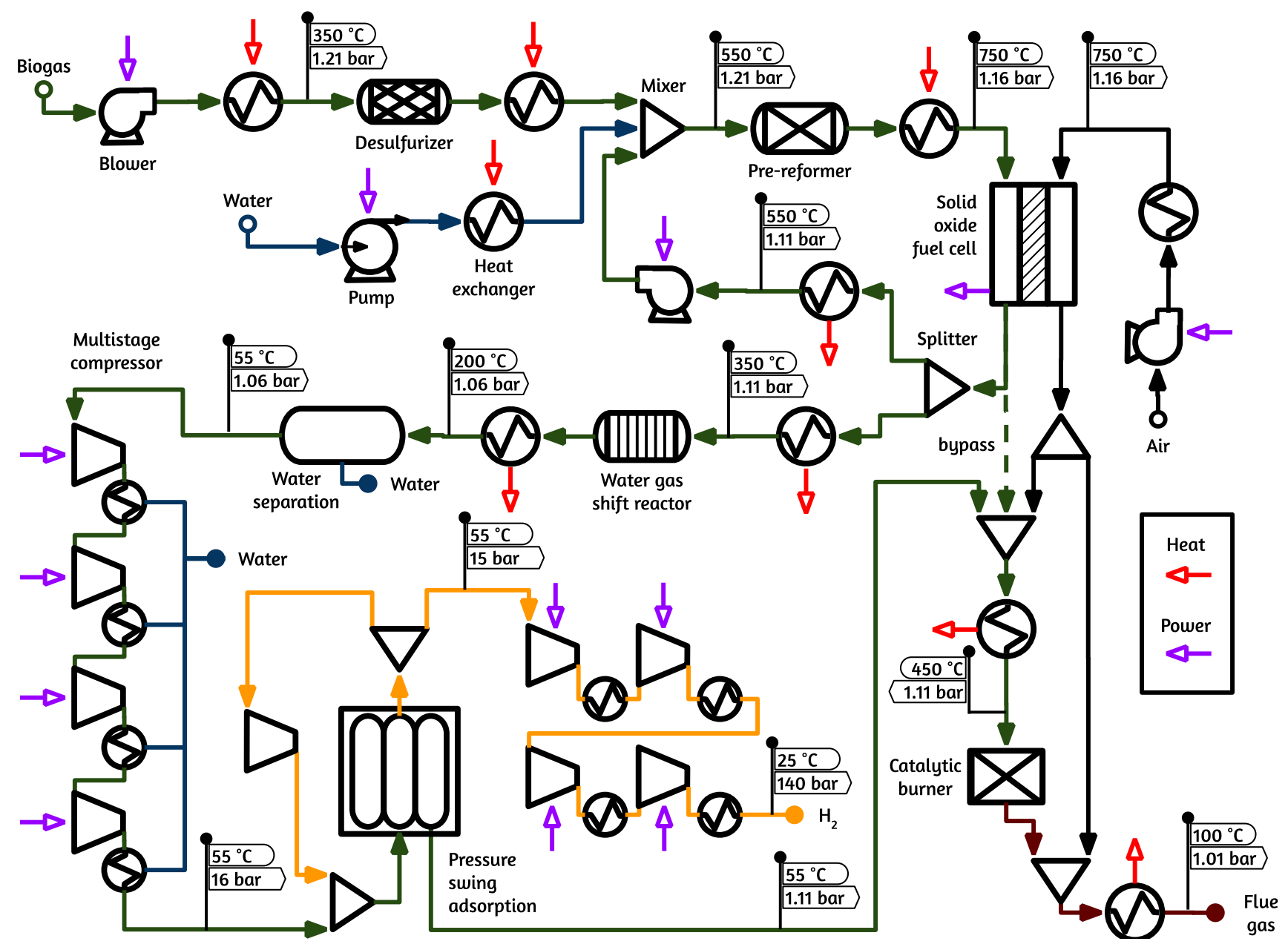

Figure 1. Process flowchart of the proposed system (Figure is in color in the on-line version of the paper). 
Conventional fuel cell systems maximize the efficiency of fuel utilization (FU) in order to increase the power generation and avoid excessive losses. However, a low quantity of hydrogen remains for biofuel production if the system converts most of the fuel into electricity. Thus, in order to provide a fair comparison between the designs, the efficiency of fuel utilization and anode recycle are different for each case. The conventional power generation system maximizes FU to $70 \%$ and recycles $50 \%$ of the anode exhaust gas. In this case, the anode recycle step consists in a cooling process followed by a recompression to prepare the recycled gas to be reinserted in the pre-reformer. On the other hand, the hydrogen co-production case reduces the FU to $50 \%$ and does not employ anode recycling.

Then, a heat exchanger cools down the non-recycled portion of the anode exhaust gas prior to the water gas shift reactor, as this allows for a higher conversion of carbon monoxide. The reactor is adiabatic and the reaction is able to achieve the state of chemical equilibrium. A flash drum separates the water by condensing it to liquid. A compression process consisted of four stages, with equal pressure ratios and an intercooling step $\left(\mathrm{T}=55{ }^{\circ} \mathrm{C}\right)$, compresses the dehumidified gas before hydrogen separation. Since the PSA requires at least $70 \%$ of hydrogen concentration (molar) in the inlet stream for technical and economical viability [2], the proposed system recycles the purified hydrogen to attain this specification. Another compression stage consisted of four stages, similar to the one previously described, which compresses the remaining portion of hydrogen to 140 bars to be stored in reinforced steel vessels. On the other hand, a parallel process mixes the purge gas with the cathode off-gas at a fixed percent of theoretical air $\left(\lambda_{\text {burner }}=200 \%\right)$ and send them to a catalytic burner. The heat exchanger network partially recovers the flue gases energy before releasing them to the atmosphere.

It is important to highlight that, the pinch analysis provides the minimal energy requirement to fulfill all energy demands and estimate the design of the heat exchanger network. This can be determined by solving a linear programming problem proposed by Papoulias and Grossmann [12] and Palazzi, et al. [4]. Table 1 shows a summary of the main assumptions of the model.

Table 1. Main model assumptions

\begin{tabular}{lc}
\hline Parameter & Value \\
\hline SOFC heat loss (\% consumed fuel LHV) & 2 \\
Max. temperature difference - SOFC stack (K) & 200 \\
Power inverter efficiency (\%) & 95 \\
Catalytic burner heat loss (\% fuel LHV) & 2 \\
Compressor/Pump isentropic efficiency (\%) & 70 \\
Compressor isentropic efficiency - Anode recycle (\%) & 50 \\
Pre-reforming pressure loss (kPa) & 5 \\
SOFC pressure drop (kPa) & 5 \\
Water gas shift reactor pressure drop (kPa) & 5 \\
Catalytic burner pressure drop (kPa) & 5 \\
PSA separation efficiency (\%) [5, 11] & 80 \\
Global temperature approach for pinch analysis (K) & 20 \\
\hline
\end{tabular}

\section{Methods}

This research developed a thermodynamic model using the Julia programming language in order to reduce computational time necessary to compute the results. The 'DifferentialEquations.jl' suite [13] was used to solve the ordinary differential equations. The CoolProp library [14],
NASA Gleen coefficients [15] and empirical correlations proposed by Fuller, et al. [16] were implemented to determine properties of pure fluids, ideal gas mixtures and binary diffusivity, respectively. The exergy analysis uses the specific chemical exergies published by Szargut [17].

Moreover, the heat exchanger network with a minimal energy requirement is determined by the solution of a linear programming problem [12]. The JuMP modeling language [18] and the GLPK package [19] were employed to solve the optimization problem.

\subsection{Solid oxide fuel cell model}

In short, the model consists of two 1-D differential equations for mass transport (flow channels and porous diffusion) and a set of algebraic equations to estimate the average voltage of the fuel cells. In this study, the methods proposed by Aguiar, et al. [20] for a planar fuel cell with internal reforming are simplified and extended with the diffusion equations proposed by Bao, et al. [21]. Figure 2 illustrates the mathematical modeling of the solid oxide fuel cells.

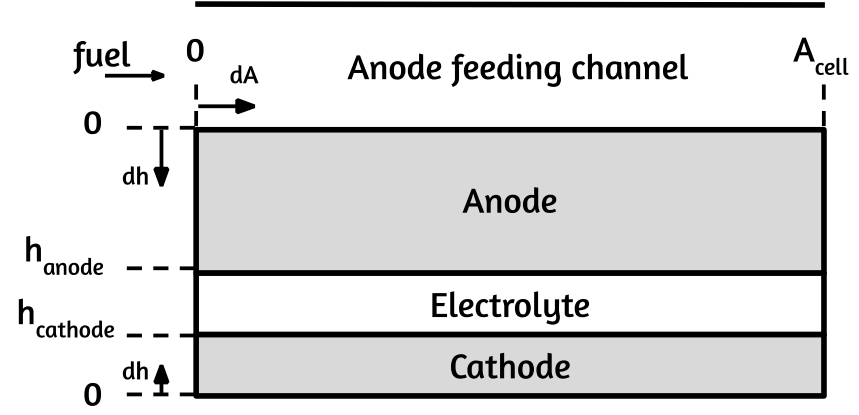

air

Cathode feeding channel

Figure 2. Coordinates and boundary conditions for the fuel cell model

The differential equation for diffusive transport estimates the molar fraction $\left(\mathrm{x}_{\mathrm{i}}\right)$ and flux $\left(\mathrm{J}_{\mathrm{i}}\right)$ of reactants along the porous electrode thickness (coordinate ' $h$ '), taking into account the reactions of water gas shift (WGS) and electrochemical oxidation (EOXY). Next, a set of equations estimates a local cell voltage (V) for an average current density (j), which is fixed along the fuel cell stack to avoid numerous iterations. Finally, the differential equation for the feeding channel includes the steam methane reforming (SMR) and calculates the molar flow rate (n) and temperature of reactants $(\mathrm{T})$ along the cell area (coordinate 'A'). It is important to highlight that only one type of mass transport is considered to be predominant for each coordinate.

In order to simplify the problem, the diffusion model uses an adapted version of the Stefan-Maxwell diffusion proposed by Bao, et al. [21] and neglects the pressure drop along the porous electrodes. In addition, the carbon monoxide oxidation is neglected as a simplification. Eqs. (1) and (2) describe the differential equations that determine the molar fractions $\left(\mathrm{x}_{\mathrm{i}}\right)$ and flux $\left(\mathrm{J}_{\mathrm{i}}\right)$, respectively. This problem has fixed boundary conditions in the electrode surface $(h=0)$ for the molar fractions and in the triple phase boundary $\left(\mathrm{h}=\mathrm{h}_{\text {electrode }}\right)$ for the molar fluxes, as shown respectively in Eqs. (3) and (4). Furthermore, the bulk concentrations in Eq. (3) are estimated based on the results for the molar balance in the fuel cell channels (to be presented). 
$\frac{d x_{i}}{d h}=\frac{R T}{P} \sum_{j=1, j \neq i}^{n} \frac{x_{i} J_{i}-x_{j} J_{i}}{D_{i j, e f f}}$

$\frac{d J_{i}}{d h}=v_{i, w g s} r_{w g s}$

$\left.x_{i}\right|_{h=0}=x_{i, b u l k}=\frac{n_{i}}{\sum n_{i}}$

$$
\left.J_{i}\right|_{h=h_{\text {electrode }}}=v_{i, \text { eoxy }} \frac{j}{2 F}
$$

In which,

$$
D_{i j, e f f}=\frac{\varepsilon}{2 \tau}\left(\frac{1}{1 / D_{i j}+1 / D_{i M}}+\frac{1}{1 / D_{i j}+1 / D_{j M}}\right)
$$$$
D_{i j}=\frac{0.0143 T^{1.75}}{P M_{i j}^{0.5}\left[\left(\sum D_{v, i}\right)^{1 / 3}+\left(\sum D_{v, j}\right)^{1 / 3}\right]^{2}}
$$

$$
M_{i j}=2\left[\frac{1}{M_{i}}+\frac{1}{M_{j}}\right]^{-1}
$$

$$
D_{i M}=\frac{2 r_{p}}{3} \sqrt{\frac{8 R T}{\pi M_{i}}}
$$

$$
r_{w g s}=0.0171 \cdot e^{-\frac{103191}{R T}}\left(x_{\mathrm{H}_{2} \mathrm{O}} x_{\mathrm{CO}}-\frac{x_{\mathrm{H}_{2}} x_{\mathrm{CO}_{2}}}{K_{e q, w g s}}\right) P^{2}
$$

$K_{e q, w g s}=e^{\left(-0.2935 Z^{3}+0.635 Z^{2}+4.1788 Z+0.3169\right)}$

$Z=\frac{1000}{T}-1$

The effective $\left(D_{i j}\right.$, eff $)$, binary $\left(D_{i j}\right)$ and Knudsen $\left(D_{i M}\right)$ diffusivities are calculated by using the Eq. (5) [21], Eqs. (6)-(7) [16] and Eq. (8) [22], respectively. In addition, the Eqs. (9)-(11) [23] determine the water gas shift reaction rate $\left(r_{\mathrm{wgs}}\right)$. Table 2 shows the cell dimensions assumed in this model, which are based on experiments reported by Jiang and Virkar [24].

The local voltage $(\mathrm{V})$ of the fuel cells is estimated based on the open current voltage $\left(\mathrm{V}^{0}\right)$ and overpotential losses $(\eta)$, as described in Eqs. (12)-(17). The set of equations suppose that the activation overpotentials $\left(\eta_{\text {act }}\right)$ in cathode and anode can be estimated by one Butler-Volmer equation, as represented in Eq. (14). Moreover, a linear approximation using the Tafel equation [25] with data reported by Jiang and Virkar [24] calibrates the exchange current density $\left(\mathrm{j}_{0}\right)$ value. The ohmic overpotential $\left(\eta_{\text {ohmic }}\right)$ is determined using the conductivity $(\sigma)$ and dimensions of the cell anode, cathode and electrolyte [20], as shown in Eq. (15) and Table 3. On the other hand, the concentration overpotential $\left(\eta_{\text {conc }}\right)$ is separated into two types, described in Eqs. (16) and (17), in order to properly account for variations in fuel and air concentrations [25].
Table 2. Cell dimensions

\begin{tabular}{lcc}
\hline Parameter & Value & Source \\
\hline Anode thickness $\left(\mathrm{h}_{\text {anode }}\right)$ & $1.1 \mathrm{~mm}$ & {$[24]$} \\
Cathode thickness $\left(\mathrm{h}_{\text {cathode }}\right)$ & $20 \mu \mathrm{m}$ & {$[24]$} \\
Electrolyte thickness $\left(\mathrm{h}_{\text {electrolyte }}\right)$ & $10 \mu \mathrm{m}$ & {$[24]$} \\
Porosity $(\varepsilon)$ & 0.54 & {$[24]$} \\
Tortuosity $(\tau)$ & 5.4 & Fitted \\
Mean pore radius $\left(\mathrm{r}_{\mathrm{p}}\right)$ & $0.5 \mu \mathrm{m}$ & {$[24]$} \\
Cell area* $\left(\mathrm{A}_{\text {cell }}\right)$ & $1.1 \mathrm{~cm}^{\wedge} 2$ & {$[24]$} \\
\hline
\end{tabular}

*only for model validation

$V=V^{0}(T)-\eta_{\text {act }}-\eta_{\text {ohmic }}-\eta_{\text {conc,act }}-\eta_{\text {conc,Nernst }}$

In which,

$V^{0}(T)=\frac{G^{0}{ }_{H_{2}}(T)+0.5 G^{0}{ }_{O_{2}}(T)-G^{0}{ }_{H_{2} O} O(T)}{2 F}$

$j=j_{0}\left(e^{\frac{2 \alpha F}{R T} \eta_{a c t}}-e^{-\frac{2(1-\alpha) F}{R T} \eta_{a c t}}\right)$

$\eta_{\text {ohmic }}=j\left(\frac{h_{\text {electrolye }}}{\sigma_{\text {electrolye }}}+\frac{h_{\text {anode }}}{\sigma_{\text {anode }}}+\frac{h_{\text {cathode }}}{\sigma_{\text {cathode }}}\right)$

$\eta_{\text {conc, act }}=\frac{R T}{2 \alpha F} \ln \left(\frac{\left.x_{H_{2}}\right|_{h=0}}{\left.x_{H_{2}}\right|_{h=h_{\text {anode }}}}\left(\frac{\left.x_{O_{2}}\right|_{h=0}}{\left.x_{O_{2}}\right|_{h=h_{\text {cathode }}}}\right)^{0.5}\right)$

$\eta_{\text {conc, Nernst }}=\frac{R T}{2 F}\left[\ln \left(\frac{\left.x_{\mathrm{H}_{2} O}\right|_{h=h_{\text {anode }}}}{\left.x_{\mathrm{H}_{2}}\right|_{h=h_{\text {anode }}}\left(\left.x_{\mathrm{O}_{2}}\right|_{h=h_{\text {cathode }}}\right)^{0.5}}\right)\right.$

$\left.+\ln \left(\frac{P_{0}}{P_{\text {cathode }}}\right)^{0.5}\right]$

A simple molar balance, as shown in Eq. (18), calculates the molar flow rate (n) in the fuel cell channels assuming that there is no significant variation of gas composition along the channel height. The differential equation employs the empirical correlations proposed by Achenbach and Riensche [26] to estimate the reaction rate of steam reforming. In addition, the Eq. (18) estimates the reaction rates of the water gas shift and electrochemical reactions based on the molar flux results derived from Eqs. (1) and (2).

Table 3. Electrochemical model parameters

\begin{tabular}{lcc}
\hline Parameter & Value / Function & Source \\
\hline$\sigma_{\text {anode }}$ & $80000[1 / \Omega . \mathrm{m}]$ & {$[12]$} \\
$\sigma_{\text {cathode }}$ & $8400[1 / \Omega . \mathrm{m}]$ & {$[12]$} \\
$\sigma_{\text {electolyte }}$ & $33400 \exp \left(-\frac{10300}{T}\right)[1 / \Omega . \mathrm{m}]$ & {$[12]$} \\
& $\left.2250 \exp \left(\frac{E_{a c t}\left(\frac{1}{R}(1073\right.}{T}-\frac{1}{T}\right)\right)\left[\mathrm{A} / \mathrm{m}^{2}\right]$ & Fitted \\
$\mathrm{j}_{0}$ & $140000[\mathrm{~J} / \mathrm{mol}]$ & {$[20]$} \\
$\mathrm{E}_{\text {act }}$ & 0.639 & Fitted \\
$\alpha$ & &
\end{tabular}


$\frac{d n_{i}}{d A}=v_{i, s m r} r_{s m r}+\left.J_{i}\right|_{h=0}$

Where,

$r_{\text {smr }}=4.272 \cdot 10^{-2} e^{-\frac{82000}{R T}} x_{C H_{4}}\left(\frac{P_{\text {anode }}}{10^{5}}\right)$

A simplified energy balance estimates the temperature of the fuel cells (T), described in Eq. (20), assuming that the fuel, air and cell components are in thermal equilibrium for each positions across the coordinate A (length $\mathrm{x}$ constant width). As it can be observed, this premise greatly reduces the number of thermal properties that have to be evaluated. Eq. (20) supposes that the heat losses ( $\left.\mathrm{Q}_{\text {loss }}\right)$ are proportional to the lower heating value of the consumed fuel, as previously shown in Table 1. The boundary conditions for Eqs. (18) and (20) are the inlet composition and temperature in the fuel cell.

$\frac{d T}{d A}=\left(\Delta H_{s m r} r_{s m r}+\left.\Delta H_{w g s} J_{C O}\right|_{h=0}+\Delta H_{\text {eoxy }} \frac{j}{2 F}\right.$

$\left.-j V-Q_{\text {loss }} / A_{\text {cell }}\right) / \sum n_{i} c_{p, i}$

Lastly, the average voltage $\left(\mathrm{V}_{\text {avg }}\right)$ is estimated by integrating the local cell voltage (V) over the cell area (A), as described in Eq. (21).

$\frac{d\left(V_{\text {avg }} A\right)}{d A}=V$

\subsubsection{Model validation}

The model was fitted and validated with the experimental data reported by Jiang and Virkar [24] for an anode supported SOFC cell (Ni+YSZ anode, YSZ-SDC electrolyte and LSC+SDC cathode) with $1.1 \mathrm{~cm}^{2}$ of cathode area. The exchange current density $\left(\mathrm{j}_{0}\right)$ and transfer coefficient $(\alpha)$ were fitted based on the activation overpotential by using a linear approximation with the Tafel equation [25] for the experimental results. The calibration of $\mathrm{j}_{0}$ and $\alpha$ assumes that the difference between the experimental results of voltage and the model solutions without the Butler-Volmer equation, Eq. (14), can be attributed to the activation overpotential.

As it can be observed in Figures 3 and 4, the simulation results were in agreement with the experimental data. For instance, for a range of $0.1 \mathrm{~A} / \mathrm{cm}^{2}$ to $1 \mathrm{~A} / \mathrm{cm}^{2}$, the maximum relative error observed were $5.7 \%$ and $7.0 \%$ for $\mathrm{H}_{2}-\mathrm{H}_{2} \mathrm{O}$ and $\mathrm{H}_{2}-\mathrm{CO}_{2}$ mixtures, respectively. The relative differences are higher for the mixture with $81 \% \quad \mathrm{CO}_{2}$ and current densities above $0.5 \mathrm{~A} / \mathrm{m}^{2}$ due to the effect of concentration losses. These deviations can be mainly attributed to simplifications in the diffusion equation, which could be reduced by extending the Stefan-Maxwell model to a Dusty-gas model [27]. The unified Butler-Volmer equation may also influence the results.

Lastly, this research also compares the model results against the experimental data reported by $\mathrm{Fu}$, et al. [28], which employed anode supported cells with similar materials arranged in stacks of 8 cells $\left(84 \mathrm{~cm}^{2}\right.$ each) [28].
Moreover, in the study of Fu, et al. [24], the SOFC stack works with a mixture of pre-reformed methane $(28.1 \%$ $\mathrm{CH}_{4}, 12.5 \% \mathrm{H}_{2}$ and $59.4 \% \mathrm{H}_{2} \mathrm{O}$ in molar basis) [28]. Table 4 shows that the estimated relative error is lower than $5.1 \%$ for a current density of $0.3 \mathrm{~A} / \mathrm{cm}^{2}$ using different fuel utilization efficiencies $(0.35$ and 0.70$)$.

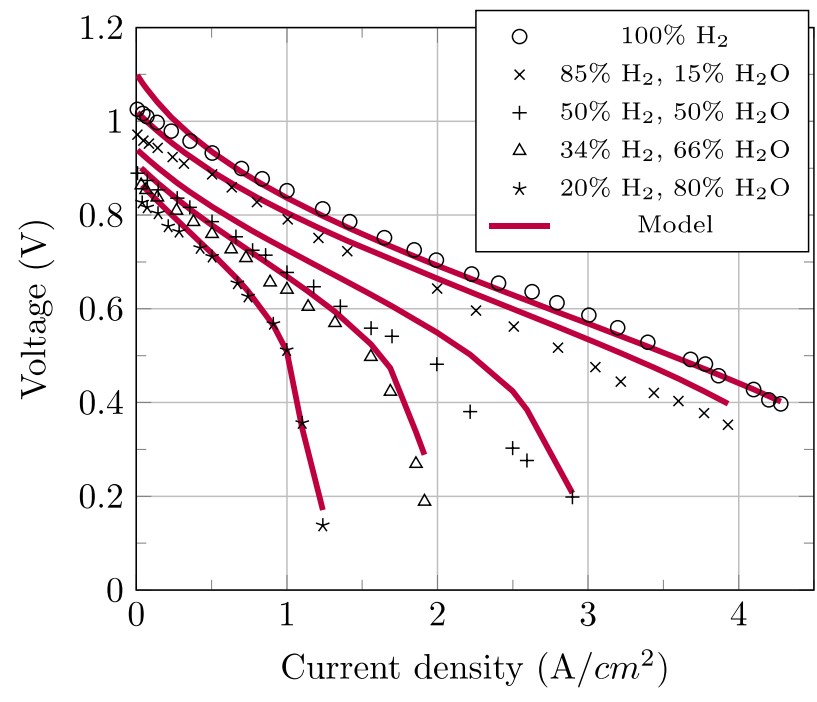

Figure 3. Model results for $\mathrm{H}_{2}-\mathrm{H}_{2} \mathrm{O}$ mixtures and experimental data reported by [24] (Figure is in color in the on-line version of the paper).

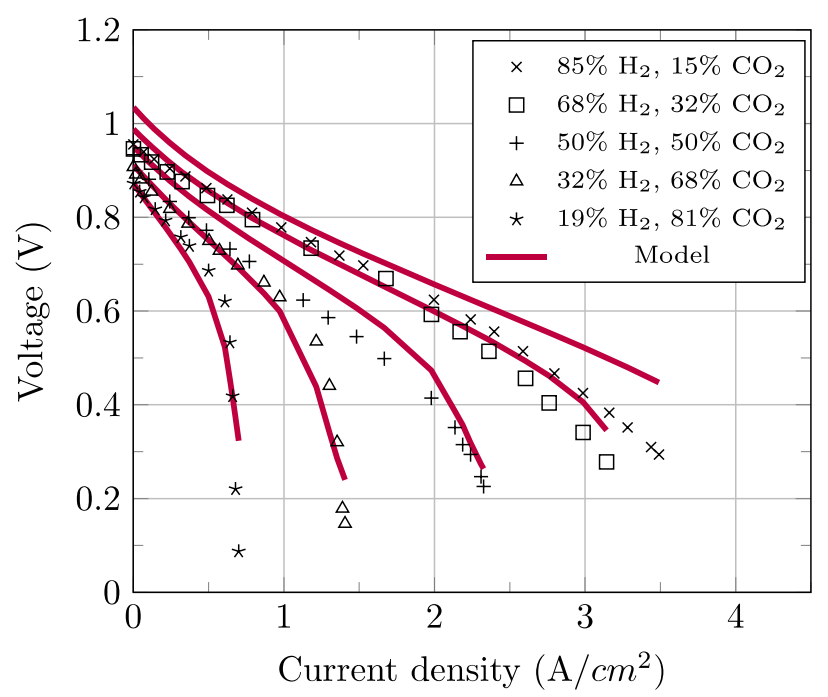

Figure 4. Model results for $\mathrm{H}_{2}-\mathrm{CO}_{2}$ mixtures and experimental data reported by [24] (Figure is in color in the on-line version of the paper).

Table 4. Comparison between model results and experimental data reported by $\mathrm{Fu}$, et al. [28]

\begin{tabular}{cccc}
\hline Operational conditions & $\begin{array}{c}\text { Experiment } \\
\text { Fu, et al. [28] }\end{array}$ & $\begin{array}{c}\text { Model } \\
\text { This work }\end{array}$ & $\begin{array}{c}\text { Difference } \\
(\%)\end{array}$ \\
\hline $\mathrm{j}=0.3 \mathrm{~A} / \mathrm{cm}^{2}$ & & & \\
$\mathrm{~T}=750^{\circ} \mathrm{C}$ & $0.82-0.83 \mathrm{~V}$ & $0.85 \mathrm{~V}$ & $2.4-3.6$ \\
$\mathrm{FU}=0.351$ & & \\
$\mathrm{j}=0.3 \mathrm{~A} / \mathrm{cm}^{2}$ & & & \\
$\mathrm{~T}=750^{\circ} \mathrm{C}$ & $0.79-0.80 \mathrm{~V}$ & $0.83 \mathrm{~V}$ & $3.6-4.8$ \\
$\mathrm{FU}=0.702$ & & & \\
\hline
\end{tabular}




\subsubsection{Auxiliary equations}

Besides the model equations described in section 3.1, the design of the proposed system also requires some auxiliary equations. In this study, the FU is treated as a design variable, while the total area of fuel cells $\left(\mathrm{A}_{\text {total }}\right)$ and percent of theoretical air $\left(\lambda_{\text {cell }}\right)$ are determined using the Eqs. (22) and (23), respectively.

$$
\begin{aligned}
& F U=\frac{j A_{\text {total }} / 2 F}{N_{H_{2}, \text { inlet }}+N_{C O, \text { inlet }}+4 N_{C H_{4}, \text { inlet }}} \\
& \frac{\lambda_{\text {cell }}}{100}=\frac{N_{\text {air }} x_{O 2, \text { air }}}{\left(0.5 N_{H_{2}, \text { inlet }}+0.5 N_{C O, \text { inlet }}+2 N_{C H_{4}, \text { inlet }}\right) F U}
\end{aligned}
$$

\subsection{Exergy analysis assumptions}

As previously mentioned, the heat exchanger network is designed at each simulation based on results of a pinch analysis including all heat transfer units. This solution method allows for design flexibility, but requires an additional assumption to evaluate the exergy destruction distribution. The simplest approach is to evaluate the heat exchanger network as a whole, as described in Eq. (24). Thus, by considering the exergy recovered from hot streams as input and the exergy delivered to cold streams as products, the analysis estimates the exergy destruction of all heat exchanger units $\left(\mathrm{B}_{\mathrm{d}, \mathrm{HXs}}\right)$. This method also assumes that temperature distribution for all heat transfers is linear, as it is considered in the pinch analysis.

$$
\begin{aligned}
& B_{d, H X s}=\sum_{h}^{H}\left|Q_{h}\right|\left(1-\frac{T_{0}}{\Delta T} \ln \left(\frac{T_{t \text { arget }}}{T_{\text {source }}}\right)\right) \\
& -\sum_{c}^{C}\left|Q_{c}\right|\left(1-\frac{T_{0}}{\Delta T} \ln \left(\frac{T_{t \text { arg et }}}{T_{\text {source }}}\right)\right)
\end{aligned}
$$

The exergy efficiency $\left(\eta_{\mathrm{ex}}\right)$ is defined as the ratio of net products per external consumption as shown in Eq. (25). In order to provide a comparison with energy analysis, energy efficiency $\left(\eta_{\mathrm{en}}\right)$ is calculated by using the definition shown in Eq. (26). In this study the consumption of external energy inputs, such as power and heat, are avoided by limiting the operational variables, therefore, Eqs. (25) and (26) do not include their expressions.

$$
\begin{aligned}
& \eta_{e x}=\frac{W_{\text {net }}+B_{H_{2}}}{B_{\text {fuel }}+B_{\text {water }}} \\
& \eta_{e n}=\frac{W_{\text {net }}+N_{H_{2}} L H V_{H_{2}}}{N_{\text {fuel }} L H V_{\text {fuel }}}
\end{aligned}
$$

\section{Results and discussion}

Table 5 shows the main technical results separated by fuel and products. The results indicate that, for these operational conditions, the fuel cells attain similar performances (<3\% difference) in voltage and power density despite working with different fuels. This can be explained by the similar initial concentrations of hydrogen in the anode inlet, caused by the fixed steam to carbon ratio and the anode off-gas recycle. For instance, the initial molar concentration of hydrogen in the biogas case is approximately $0.12-0.14$, while for biomethane the value is

\begin{tabular}{|c|c|c|c|c|}
\hline \multirow[b]{2}{*}{ Description } & \multicolumn{2}{|c|}{ Biogas } & \multicolumn{2}{|c|}{ Biomethane } \\
\hline & Power & $\begin{array}{c}\text { Power+ } \\
\mathrm{H}_{2}\end{array}$ & Power & $\begin{array}{c}\text { Power+ } \\
\mathrm{H}_{2}\end{array}$ \\
\hline \multicolumn{5}{|l|}{ Pre-reforming } \\
\hline $\mathrm{T}_{\text {outlet }}\left({ }^{\circ} \mathrm{C}\right)$ & 465 & 417 & 468 & 395 \\
\hline$\Delta \mathrm{CH}_{4}(\%)$ & 24 & 16 & 15 & 12 \\
\hline $\begin{array}{l}\text { Water consumption } \\
(1 / \mathrm{h})\end{array}$ & 121 & 161 & 63 & 97 \\
\hline Inlet $\mathrm{O} / \mathrm{C}$ ratio & 3.29 & 4.67 & 2.95 & 2.95 \\
\hline \multicolumn{5}{|l|}{ SOFC } \\
\hline$\Delta \mathrm{T}\left({ }^{\circ} \mathrm{C}\right)$ & 177 & 113 & 200 & 134 \\
\hline $\mathrm{T}_{\max }\left({ }^{\circ} \mathrm{C}\right)$ & 893 & 781 & 889 & 771 \\
\hline $\mathrm{T}_{\min }\left({ }^{\circ} \mathrm{C}\right)$ & 716 & 668 & 688 & 638 \\
\hline Area $\left(\mathrm{m}^{2}\right)$ & 158 & 96 & 158 & 96 \\
\hline Voltage (V per cells) & 0.75 & 0.76 & 0.78 & 0.76 \\
\hline Power (kW) & 338 & 206 & 349 & 208 \\
\hline $\begin{array}{l}\text { Power density } \\
\left(\mathrm{W} / \mathrm{m}^{2}\right)\end{array}$ & 2144 & 2157 & 2216 & 2172 \\
\hline \multicolumn{5}{|l|}{ Burner } \\
\hline $\mathrm{T}_{\max }\left({ }^{\circ} \mathrm{C}\right)$ & 871 & 1155 & 966 & 1176 \\
\hline \multicolumn{5}{|l|}{ Water gas shift } \\
\hline $\mathrm{T}_{\text {outlet }}\left({ }^{\circ} \mathrm{C}\right)$ & & 405 & & 413 \\
\hline$\Delta \mathrm{CO}(\%)$ & & 83 & & 79 \\
\hline \multicolumn{5}{|l|}{ PSA } \\
\hline $\begin{array}{c}\mathrm{H}_{2} \text { initial } \\
\text { concentration }\end{array}$ & & $\begin{array}{c}0.52 \\
(\text { molar })\end{array}$ & & $\begin{array}{c}0.65 \\
(\text { molar })\end{array}$ \\
\hline Recycle ratio (\%) & & 66 & & 26 \\
\hline $\begin{array}{l}\text { Separation effective } \\
\text { efficiency }(\%)\end{array}$ & & 58 & & 63 \\
\hline \multicolumn{5}{|l|}{ Products } \\
\hline Net power $(\mathrm{kW})$ & 319 & 158 & 333 & 163 \\
\hline $\mathrm{H}_{2}(\mathrm{~kg} / \mathrm{d})$ & & 139 & & 182 \\
\hline
\end{tabular}
between 0.14-0.18. Furthermore, at low current densities, the impact of overpotential losses related to reactants concentration is low, which also can be observed in experimental data reported by Jiang and Virkar [24].

Table 5. Main technical results for base cases

Table 6 presents the result for the energy analysis of each proposed scenario. As it can be observed, the hydrogen purification unit doubles the power consumption in the system (214-229\%), since high pressures are necessary for hydrogen purification and storage. On the other hand, the hydrogen production is sufficient to obtain a surplus in energy and increase the overall energy efficiency (11-26\%). However, the net energy gain using biogas as fuel $(+154 \mathrm{~kW})$ is significantly lower compared with the biomethane scenario $(+218 \mathrm{~kW})$. In fact, one may argue that in an extended analysis including the hydrogen final use (e.g., $50 \%$ efficiency) the co-production of hydrogen may reduce the overall efficiency. This dilemma between production and end-use efficiency has also been reported for other production systems co-producing electricity and biofuels [3]. Thus, these results indicate that the proposed system could be more profitable, given its better efficiency, but may not score as well as conventional SOFC systems in environmental performance. 
Table 6. Energy analysis for base cases

\begin{tabular}{lcccc}
\hline & \multicolumn{2}{c}{ Biogas } & \multicolumn{2}{c}{ Biomethane } \\
\cline { 2 - 5 } & Power & $\begin{array}{c}\text { Power } \\
+\mathrm{H}_{2}\end{array}$ & Power & $\begin{array}{c}\text { Power } \\
+\mathrm{H}_{2}\end{array}$ \\
\hline $\begin{array}{l}\text { Power consumption or } \\
\text { generation }(k W)\end{array}$ & & & & \\
$\quad$ Biogas compressor & -0.8 & -0.8 & -0.5 & -0.5 \\
$\quad$ Water pump & $\sim 0$ & $\sim 0$ & $\sim 0$ & $\sim 0$ \\
$\quad$ Air compressor & -9.9 & -7.0 & -9.9 & -7.0 \\
$\quad$ SOFC + inverter & 338.9 & 206.4 & 349 & 207.9 \\
$\quad \begin{array}{l}\text { Recycle compressor } \\
\text { PSA multistage }\end{array}$ & -8.4 & & -5.7 & \\
compressor & - & -32.6 & - & -26.8 \\
$\quad$ PSA recycle & - & -0.4 & - & -0.1 \\
compressor & & & & \\
$\quad \mathrm{H}_{2}$ multistage & - & -7.9 & - & -10.3 \\
compressor & & & & \\
Hydrogen energy $(k W)$ & - & 195.2 & - & 225.1 \\
Energy efficiency $(\%)$ & 52.2 & 57.7 & 54.5 & 68.4 \\
\hline
\end{tabular}

The results for energy efficiency presented in Table 6 are in agreement with previous studies of similar systems. For instance, Fontell, et al. [29] estimated a net electrical efficiency of $55.9 \%$ for a SOFC system designed for natural gas. Peters, et al. [30] reported a net electrical efficiency between $40-50 \%$ for a SOFC demonstration unit of $20 \mathrm{~kW}$ operating with natural gas. For systems working with biogas, Van Herle, et al. [6] determined an energy efficiency of $48.7 \%$, while Curletti, et al. [7] calculated a value close to $50 \%(\mathrm{FU}=70 \%)$. Dietrich, et al. [31] observed an energy efficiency of $52 \%$ for a $1 \mathrm{~kW} \mathrm{SOFC}$ module operating with a biogas mixture containing $55 \%$ of methane (in volume). Moreover, Gandiglio, et al. [1] reported an average energy efficiency of $50-52 \%$ for an industrial size SOFC plant that works with biogas. For systems co-producing hydrogen and electricity, results published by Becker, et al. [2] indicated an efficiency of 62$65 \%$, considering natural gas as fuel and excluding the contribution from heat cogeneration. In addition, PérezFortes, et al. [5] also calculated efficiencies between 53$67 \%$ for a pilot SOFC unit producing hydrogen and electricity using natural gas.

In general, the different values of energy efficiency can be attributed to design choices (e.g., anode recycle, reforming, operational variables), electrode materials and analysis assumptions. For instance, Gandiglio, et al. [1] does not include the power consumption for biogas and air compression in their calculations for energy efficiency, which may induce an overestimate for efficiency. Besides, the mathematical modeling of previous studies does not provide crucial information to evaluate technical restraints of fuel cells, such as minimal fuel concentration and local temperature. For example, Curletti, et al. [7] neglects the effect of fuel consumption along the fuel cells, which may lead to misleading results of performance for high efficiencies of fuel utilization. The present analysis also shows that, although previous studies have indicated substantial increases in efficiency by co-producing hydrogen [2,5], these improvements are significantly lower for systems using biogas as fuel. The comparison between the results for biomethane and biogas operation in Table 6 demonstrates these differences.

\subsection{Energy integration results}

Figure 5 shows the grand composite curves for each scenario derived from the pinch analysis. It can be noticed that the power generation cases have a large potential for heat cogeneration (124-152 kW), which is greatly reduced with hydrogen co-production $(22-27 \mathrm{~kW})$. This difference can be explained by the reduction of fuel sent to the catalytic burner due to the separation of hydrogen. Since biogas production often requires an energy demand for temperature control, a reduction in the energy available as heat may be undesirable. For example, the heating of anaerobic reactors may require an extra consumption of fuel in order to maintain the biogas productivity [32]. However, the heating demand for anaerobic digestion may not be a concern for industrial wastewater [33], in which the feedstock may be at elevated temperatures, or landfills. Thus, hydrogen production is an interesting option for these processes, since they are not very dependent on the heating supply from power generation.

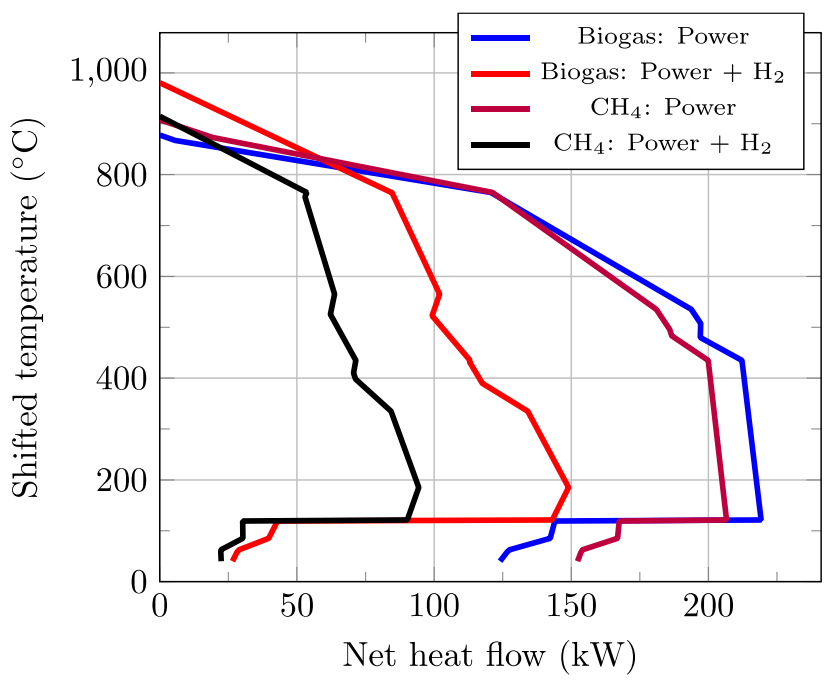

Figure 5. Grand composite curves from pinch analysis (Figure is in color in the on-line version of the paper).

On the other hand, Figure 5 also shows that steam generation has a large impact on the available heat for cogeneration. For instance, the scenario of power generation using biomethane has the largest potential for heat cogeneration and also the lowest water consumption, as shown in Table 5. Thus, a reduction in steam consumption may benefit the energy efficiency when heat is a desirable product. However, steam also reduces the formation of soot and promotes the hydrogen generation in methane reforming according to the chemical equilibrium principle; therefore the steam to carbon ratio should be optimized. These trade-offs are very similar to those reported for hydrogen production in steam reforming units [11].

\subsection{Exergy analysis results}

Figure 6 shows the values of exergy efficiency for the different scenarios evaluated in this study. As it can be observed, the values are close to those for energy efficiency, since the lower heating value and specific chemical exergy of fuels are similar. Hydrogen production is able to significantly boost the exergy efficiency by avoiding key losses in energy conversion, as illustrated in the exergy destruction breakdown on Figure 7. 


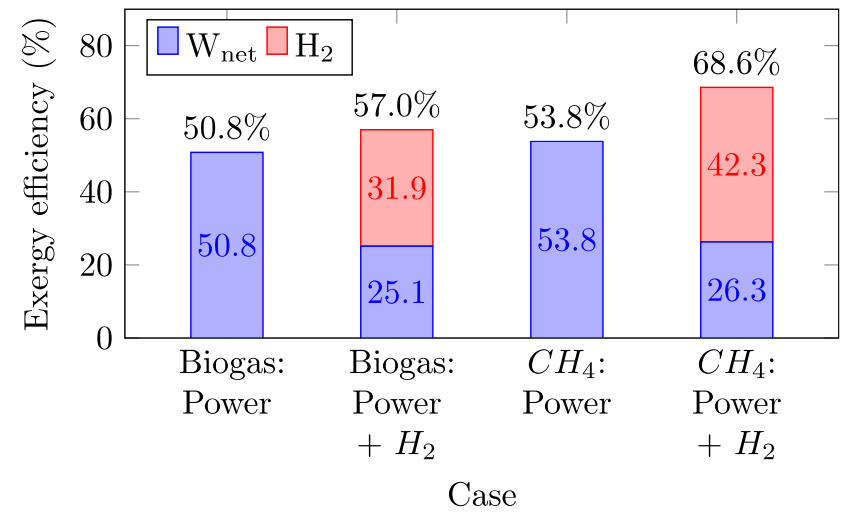

Figure 6. Exergy efficiency for base cases (Figure is in color in the on-line version of the paper).

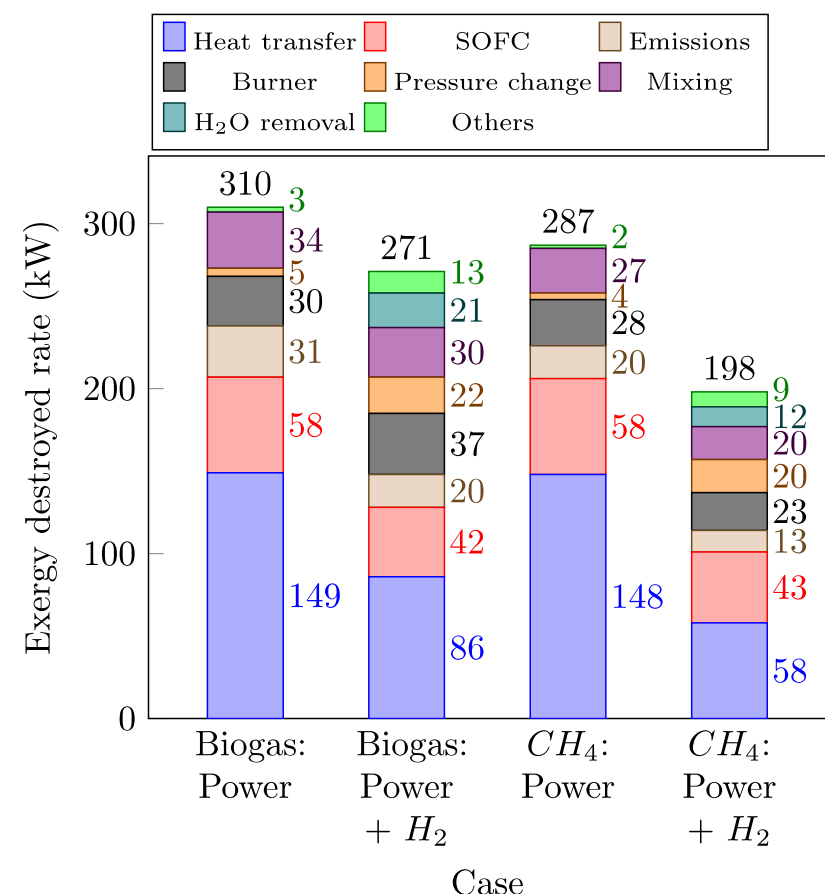

Figure 7. Exergy destroyed assessment for base cases (Figure is in color in the on-line version of the paper).

The exergy destruction assessment indicates that the heat exchanger network is the major source of irreversibility in all scenarios $(31-50 \%)$. This can be explained by the unexplored potential for heat cogeneration and high temperature differences, as previously shown in the energy integration results. For instance, for hydrogen production cases, the lower amount of fuel converted to heat indirectly reduces the losses in the heat exchanger network. Thus, future improvements can be achieved with heat cogeneration or reductions in fuel combustion promoted by higher separation efficiencies.

Figure 7 also shows that the solid oxide fuel cell is a relevant source of exergy destroyed. The activation overpotential, low concentration of hydrogen and power inverter efficiency leads to significant losses which explain this result. Moreover, the exergy destruction for hydrogen co-production cases is relatively high compared with power generation despite the reduction in fuel utilization efficiency. This can be explained by the lower operating temperature, as shown in Table 5 , which reduces the physical exergy of outlet gases. A simple alternative to increase the efficiency of solid oxide fuel cells is to operate it at higher pressures [9, 25]. However, the additional power consumption for pressurization may overcome the benefits of a higher cell voltage. A proposed alternative is to include a turbine to produce more electricity from the anode exhaust gases, such as in the hybrid configurations of SOFC with gas turbines (SOFC-GT) [34].

These results have minor disagreements with previous studies that investigated the exergy analysis of SOFC systems, mostly for natural gas and hydrogen operation. For instance, Bedringås, et al. [35] reported the fuel preheating as the major source of irreversibilities in SOFC systems, but indicate the after-burner as the second largest source followed by the SOFCs. A similar conclusion can be inferred based on the results of other authors, such as Chan, et al. [36], Gandiglio, et al. [37] and Lee, et al. [38]. These deviations can be explained by the differences in the fuel reforming and control volumes used in the exergy analysis of previous researches compared with the present study. For instance, although the internal reforming can simplify the heat management, it adds more irreversibilities to the SOFCs compared with systems using indirect or external reforming, such as those aforementioned. In addition, the exergy analysis shown in Figure 7 separates the irreversibilities of mixing fuel and air from the reaction of both substances. Thus, if both processes were joined into the control volume for the catalytic burner, the exergy destruction of this equipment would be higher.

Other major sources of exergy destruction can be linked with irreversible reactions (Burner) and the mixture of streams with different temperatures or compositions (Mixing). The scenarios with hydrogen production also include significant losses in multistage compressors (Pressure change), which could be avoided by improving the equipment efficiency or lowering the pressure for hydrogen separation. Furthermore, since the analysis assumes that energy derived from water condensation is unsuitable for heating cold streams, the exergy destruction in the process of water removal is relatively high.

\subsection{Sensitivity analysis}

Figure 8 presents the impact of some key operational parameters in the exergy efficiency of hydrogen and electricity co-production using biogas. In addition, Figure 9 shows the influence of certain assumptions on exergy efficiency. It is important to highlight that the range of some variables was limited to avoid technical complications, such as negative pressures, elevated temperatures or external heat demand.

As it can be observed, the stack temperature has a high influence in the exergy efficiency, since it heavily impacts on the exchange current density, conductivity of materials and open current voltage. Although higher temperatures could lead to significant gains in efficiency, they may require expensive materials for inter-connectors, gaskets and other auxiliary equipment $[9,25]$. Thus, technical and economic factors should be considered in the optimization of SOFC design variables [7, 34].

On the other hand, the efficiency of fuel utilization and the current density have a relatively low effect on exergy efficiency ( $\pm 5 \%$ for a $\pm 20 \%$ variation). Moreover, changes in the steam to carbon ratio, percent of theoretical air and stack pressure do not significantly alter the exergy efficiency. This may be explained by the multiple effects these parameters have in the system. For instance, a 
reduction in steam to carbon ratio may decrease the water concentration, but also diminishes the methane reforming yield [39]. The superposition of positive and negative changes may result in a small effect in exergy efficiency.

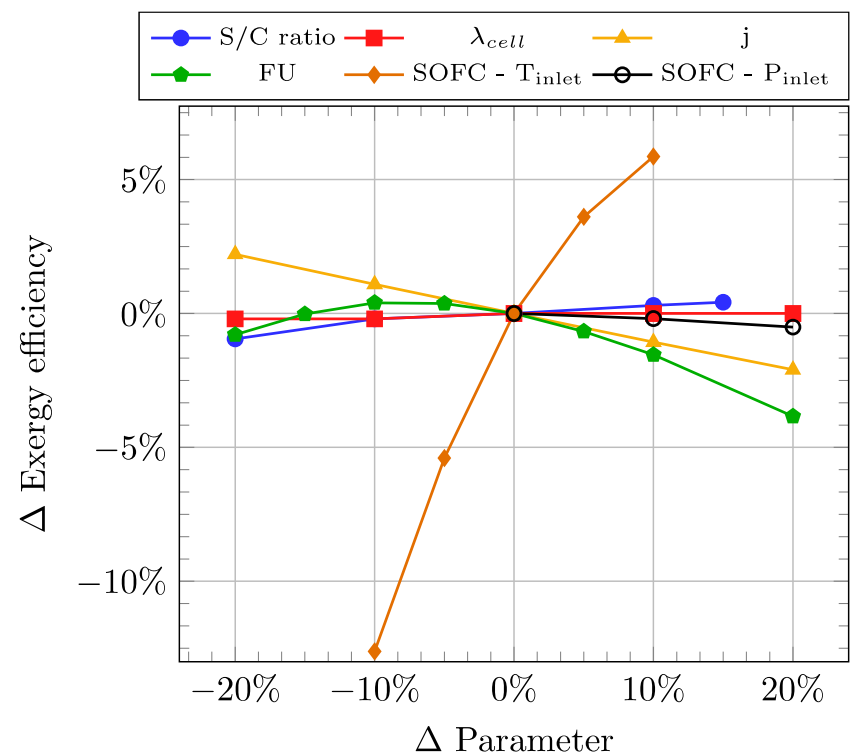

Figure 8. Sensitivity analysis of operational conditions for the co-production of $\mathrm{H}_{2}$ and electricity using biogas (Figure is in color in the on-line version of the paper).

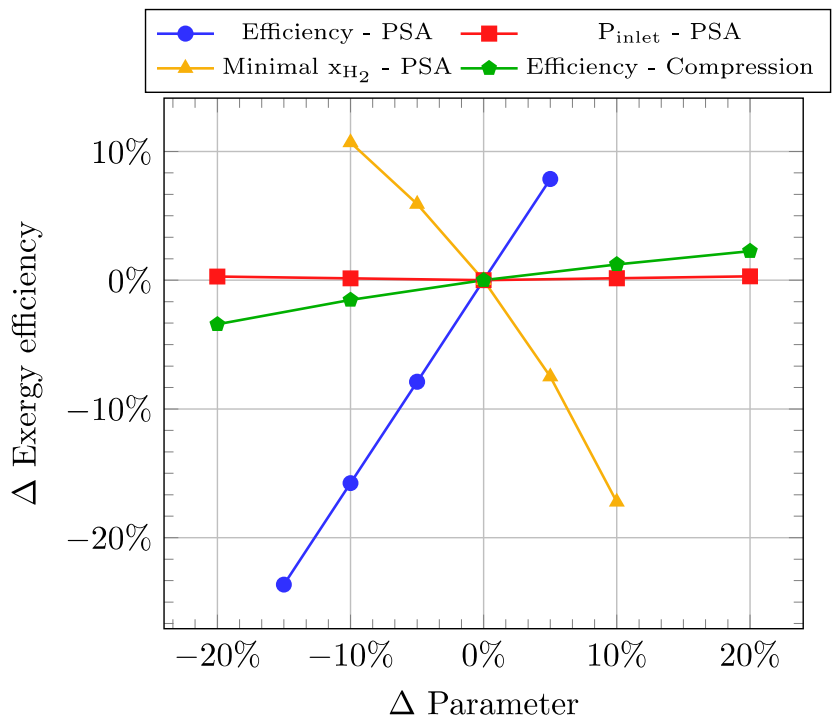

Figure 9. Sensitivity analysis of main assumptions for the co-production of $\mathrm{H}_{2}$ and electricity using biogas (Figure is in color in the on-line version of the paper).

Lastly, it is clear that the PSA separation efficiency and minimal hydrogen concentration have a huge impact in the proposed system $( \pm 10 \%$ for a $\pm 10 \%$ variation). Thus, a detailed analysis and optimization of hydrogen separation could lead to great improvements and reduce risks related with uncertainties in the system performance [40]. The analysis also points out that variations in the PSA inlet pressure or compressors efficiency may not directly lead to significant gains in performance.

\section{Conclusions}

In this research, a model for a solid oxide fuel cell (SOFC) with internal reforming was adapted and validated with experimental data reported by other researchers. The study proposes a system producing hydrogen and electricity using biogas evaluates its performance compared with a conventional SOFC system. Next, the differences between the operation with biogas and biomethane were also evaluated and discussed.

The results indicate that a small plant producing 100 $\mathrm{Nm}^{3} / \mathrm{h}$ of biogas is able to deliver $139 \mathrm{~kg} / \mathrm{d}$ of $\mathrm{H}_{2}$ and 158 $\mathrm{kW}$ of electricity, which represents an exergy efficiency of $57 \%$. This performance is $10.5 \%$ higher than conventional SOFC systems producing electricity and can attain a maximum of $68.6 \%$ exergy efficiency with biomethane operation. It is important to highlight that these results directly impact the economic return of biogas use and, therefore, the system may increase the revenues of biogas plants.

The gains in performance promoted by hydrogen production are related with the reduction of fuel conversion into heat, which was not considered as a product in this analysis. The pinch analysis results shows that hydrogen production greatly reduces the heat cogeneration potential $(-82 \%)$, which may be an undesirable feature if biogas production has high energy demand for temperature control.

In addition, the exergy analysis pinpoints the heat exchanger network (31-50\%), SOFC (19-22\%) and catalytic burner $(10-14 \%)$ to be the main sources of irreversibilities of the analyzed systems. Thus, exporting heat as a product or increasing the hydrogen separation and SOFC efficiencies can offer major performance improvements.

The sensitivity analysis of key operational variables and model assumptions also presented similar results. The SOFC temperature, PSA separation efficiency and the minimal concentration of hydrogen at the PSA inlet have huge effects in the exergy efficiency $( \pm 5-10 \%$ for a $\pm 10 \%$ variation). This analysis also demonstrated that changes in the current density, fuel utilization and compression efficiency cause minor effects on the system efficiency $( \pm$ $5 \%$ for a $\pm 20 \%$ variation). Thus, the optimization of hydrogen separation and SOFC operation parameters could lead to significant performance improvements and minimize uncertainties in the results.

\section{Acknowledgements:}

This study was financed in part by the Coordenação de Aperfeiçoamento de Pessoal de Nível Superior - Brasil (CAPES) - Finance Code 001. The first author acknowledges CAPES for his $\mathrm{PhD}$ grant and the second author acknowledges CNPq (Brazilian National Council for Scientific and Technological Development) for the grant 304935/2016-6.

\section{Nomenclature}

\section{Variables}

A: cell area $\left(\mathrm{m}^{2}\right)$

B: exergy flow rate $(\mathrm{W})$

$\mathrm{c}_{\mathrm{p}}$ : specific heat capacity at constant pressure $(\mathrm{J} / \mathrm{mol} . \mathrm{K})$

$\mathrm{D}_{\mathrm{ij}}$ : binary diffusivity $\left(\mathrm{m}^{2} / \mathrm{s}\right)$

$\mathrm{D}_{\mathrm{ij}, \text { eff: }}$ effective binary diffusivity $\left(\mathrm{m}^{2} / \mathrm{s}\right)$

$\mathrm{D}_{\mathrm{iM}}$ : Knudsen diffusivity $\left(\mathrm{m}^{2} / \mathrm{s}\right)$

$\mathrm{D}_{\mathrm{v}}$ : diffusion volumes

$E_{\text {act }}$ activation energy $(\mathrm{J} / \mathrm{mol})$

F: Faraday constant (s.A/mol) 
FU: Fuel utilization efficiency

G: Gibbs free energy $(\mathrm{J} / \mathrm{mol})$

$\mathrm{H}$ : enthalpy $(\mathrm{J} / \mathrm{mol})$

$\mathrm{h}$ : electrode height position $(\mathrm{m})$

$\mathrm{J}_{\mathrm{i}}$ : molar flux $\left(\mathrm{mol} /\left(\mathrm{m}^{2} . \mathrm{s}\right)\right)$

$\mathrm{j}_{0}$ : exchange current density $\left(\mathrm{A} / \mathrm{m}^{2}\right)$

$\mathrm{Z}$ : temperature factor

$\mathrm{K}_{\text {eq,wgs: }}$ equilibrium constant

$\mathrm{M}_{\mathrm{i}}$ : molar weight $(\mathrm{g} / \mathrm{mol})$

$\mathrm{M}_{\mathrm{ij}}$ : molar weight factor

$\mathrm{n}_{\mathrm{i}}$ : molar flow rate $(\mathrm{mol} / \mathrm{s})$

$\mathrm{P}$ : pressure $(\mathrm{Pa})$

$\mathrm{Q}$ : heat transfer (W)

$\mathrm{r}_{\mathrm{p}}$ : mean pore radius $(\mathrm{m})$

$\mathrm{r}_{\mathrm{wgs}}, \mathrm{r}_{\mathrm{smr}}$ reaction rate $\left(\mathrm{mol} /\left(\mathrm{m}^{2} . \mathrm{s}\right)\right.$ or $\left.\mathrm{mol} /\left(\mathrm{m}^{3} . \mathrm{s}\right)\right)$

$\mathrm{R}$ : gas constant $(\mathrm{J} / \mathrm{mol} . \mathrm{K})$

$\mathrm{T}$ : temperature $(\mathrm{K})$

$\mathrm{V}$ : voltage $(\mathrm{V})$

$\mathrm{V}^{0}$ : open current voltage $(\mathrm{V})$

$\mathrm{v}_{\mathrm{i}, \mathrm{smr}}, \mathrm{v}_{\mathrm{i} \text {,wgs }}$ and $\mathrm{v}_{\mathrm{i} \text {,eoxy }}$ : stoichiometric coefficients

$\mathrm{X}_{\mathrm{i}}$ : molar fraction

\section{Greek letters}

$\alpha$ : transfer coefficient

$\varepsilon$ : porosity

$\lambda$ : percent of theoretical air $(\%)$

$\eta$ : overpotential $(\mathrm{V})$ or efficiency

$\sigma$ : conductivity $(1 / \Omega . m)$

$\tau$ : tortuosity

\section{Acronyms}

EOXY: electrochemical oxidation

HXs: heat exchanger units

LHV: lower heating value

PSA: pressure swing adsorption

SOFC: solid oxide fuel cell

WGS: water gas shift reaction

\section{References:}

[1] M. Gandiglio, A. Lanzini, M. Santarelli, M. Acri, T. Hakala, and M. Rautanen, "Results from an industrial size biogas-fed SOFC plant (the DEMOSOFC project)," International Journal of Hydrogen Energy, vol. 45, no. 8, pp. 5449-5464, Feb. 2020, doi: 10.1016/j.ijhydene.2019.08.022.

[2] W. L. Becker, R. J. Braun, M. Penev, and M. Melaina, "Design and technoeconomic performance analysis of a 1MW solid oxide fuel cell polygeneration system for combined production of heat, hydrogen, and power," Journal of Power Sources, vol. 200, pp. 34-44, Feb. 2012, doi: 10.1016/j.jpowsour.2011.10.040.

[3] R. Nogueira Nakashima, D. Flórez-Orrego, H. I. Velásquez, and S. D. O. Junior, "Sugarcane bagasse and vinasse conversion to electricity and biofuels: an exergoeconomic and environmental assessment," IJEX, vol. 33, no. 1, p. 44, 2020, doi: 10.1504/IJEX.2020.109623.

[4] F. Palazzi, N. Autissier, F. M. A. Marechal, and D. Favrat, "A methodology for thermo-economic modeling and optimization of solid oxide fuel cell systems," Applied Thermal Engineering, vol. 27, no. 16, pp. 2703-2712, Nov. 2007, doi: 10.1016/j.applthermaleng.2007.06.007.
[5] M. Pérez-Fortes et al., "Design of a Pilot SOFC System for the Combined Production of Hydrogen and Electricity under Refueling Station Requirements," Fuel Cells, vol. 19, no. 4, pp. 389-407, May 2019, doi: 10.1002/fuce.201800200.

[6] J. Van herle, F. Maréchal, S. Leuenberger, Y. Membrez, O. Bucheli, and D. Favrat, "Process flow model of solid oxide fuel cell system supplied with sewage biogas," Journal of Power Sources, vol. 131, no. 1-2, pp. 127141, May 2004, doi: 10.1016/j.jpowsour.2004.01.013.

[7] F. Curletti, M. Gandiglio, A. Lanzini, M. Santarelli, and F. Maréchal, "Large size biogas-fed Solid Oxide Fuel Cell power plants with carbon dioxide management: Technical and economic optimization," Journal of Power Sources, vol. 294, pp. 669-690, Oct. 2015, doi: 10.1016/j.jpowsour.2015.06.091.

[8] M. MosayebNezhad, A. S. Mehr, M. Gandiglio, A. Lanzini, and M. Santarelli, "Techno-economic assessment of biogas-fed CHP hybrid systems in a real wastewater treatment plant," Applied Thermal Engineering, vol. 129, pp. 1263-1280, Jan. 2018, doi: 10.1016/j.applthermaleng.2017.10.115.

[9] J. Larminie and A. Dicks, Fuel Cell Systems Explained. West Sussex, England: John Wiley \& Sons, Ltd, 2003.

[10] IEA, "Outlook for biogas and biomethane: Prospects for organic growth," IEA, Paris, 2020. [Online], Available: https://www.iea.org/reports/outlook-forbiogas-and-biomethane-prospects-for-organic-growth. [Accessed: May 10, 2021].

[11] P. Häussinger, R. Lohmüller, and A. M. Watson, "Hydrogen, 2. Production," in Ullmann's Encyclopedia of Industrial Chemistry, Wiley-VCH Verlag GmbH \& Co. KGaA, Ed. Weinheim, Germany: Wiley-VCH Verlag $\mathrm{GmbH} \&$ Co. KGaA, 2011, doi: 10.1002/14356007.o13_o23.

[12] S. A. Papoulias and I. E. Grossmann, "A structural optimization approach in process synthesis-II," Computers \& Chemical Engineering, vol. 7, no. 6, pp. 707-721, Jan. 1983, doi: 10.1016/0098-1354(83)850236.

[13] C. Rackauckas and Q. Nie, "Differentialequations.jl-a performant and feature-rich ecosystem for solving differential equations in julia," Journal of Open Research Software, vol. 5, no. 1, 2017.

[14] I. H. Bell, J. Wronski, S. Quoilin, and V. Lemort, "Pure and Pseudo-pure Fluid Thermophysical Property Evaluation and the Open-Source Thermophysical Property Library CoolProp," Ind. Eng. Chem. Res., vol. 53, no. 6, pp. 2498-2508, Feb. 2014, doi: 10.1021/ie4033999.

[15] B. J. McBride, M. J. Zehe, and S. Gordon, "NASA Glenn Coefficients for Calculating Thermodynamic Properties of Individual Species," NASA Glenn Research Center, Cleveland, OH United States, NASA/TP-2002-211556, 2002.

[16] E. N. Fuller, P. D. Schettler, and J. C. Giddings, "New method for prediction of binary gas-phase diffusion coefficients," Ind. Eng. Chem., vol. 58, no. 5, pp. 18-27, May 1966, doi: 10.1021/ie50677a007. 
[17] J. Szargut, Exergy method: technical and ecological applications. Southampton; Boston: WIT Press, 2005.

[18] I. Dunning, J. Huchette, and M. Lubin, "JuMP: A Modeling Language for Mathematical Optimization," SIAM Review, vol. 59, no. 2, pp. 295-320, 2017, doi: $10.1137 / 15 \mathrm{M} 1020575$.

[19] A. Makhorin, GLPK (GNU Linear Programming Kit). [Online]. Moscow, Russia: Department for Applied Informatics, Moscow Aviation Institute, 2012. Available: $\quad$ https://www.gnu.org/software/glp. [Accessed: May 5, 2021].

[20] P. Aguiar, C. S. Adjiman, and N. P. Brandon, "Anodesupported intermediate temperature direct internal reforming solid oxide fuel cell. I: model-based steadystate performance," Journal of Power Sources, vol. 138, no. 1-2, pp. 120-136, Nov. 2004, doi: 10.1016/j.jpowsour.2004.06.040.

[21] C. Bao, Z. Jiang, and X. Zhang, "Modeling mass transfer in solid oxide fuel cell anode: I. Comparison between Fickian, Stefan-Maxwell and dusty-gas models," Journal of Power Sources, vol. 310, pp. 3240, Apr. 2016, doi: 10.1016/j.jpowsour.2016.01.099.

[22] R. B. Bird, W. E. Stewart, and E. N. Lightfoot, Transport phenomena, Rev. 2. ed. New York: Wiley, 2007.

[23] B. A. Haberman and J. B. Young, "Three-dimensional simulation of chemically reacting gas flows in the porous support structure of an integrated-planar solid oxide fuel cell," International Journal of Heat and Mass Transfer, vol. 47, no. 17-18, pp. 3617-3629, Aug. 2004, doi: 10.1016/j.ijheatmasstransfer.2004.04.010.

[24] Y. Jiang and A. V. Virkar, "Fuel Composition and Diluent Effect on Gas Transport and Performance of Anode-Supported SOFCs," J. Electrochem. Soc., vol. 150, no. 7, p. A942, 2003, doi: 10.1149/1.1579480.

[25] R. O'Hayre, S.-W. Cha, W. Colella, and F. B. Prinz, Fuel Cell Fundamentals. Hoboken, NJ, USA: John Wiley \& Sons, Inc, 2016.

[26] E. Achenbach and E. Riensche, "Methane/steam reforming kinetics for solid oxide fuel cells, "Journal of Power Sources, vol. 52, no. 2, pp. 283-288, Dec. 1994, doi: 10.1016/0378-7753(94)02146-5.

[27] C. Bao, Z. Jiang, and X. Zhang, "Modeling mass transfer in solid oxide fuel cell anode: II. H2/CO cooxidation and surface diffusion in synthesis-gas operation," Journal of Power Sources, vol. 324, pp. 261-271, Aug. 2016, doi: 10.1016/j.jpowsour.2016.05.088.

[28] Q. Fu, P. Freundt, J. Bomhard, and F. Hauler, "SOFC Stacks Operating under Direct Internal Steam Reforming of Methane," Fuel Cells, vol. 17, no. 2, pp. 151-156, Apr. 2017, doi: 10.1002/fuce.201600078.

[29] E. Fontell, T. Kivisaari, N. Christiansen, J.-B. Hansen, and J. Pålsson, "Conceptual study of a $250 \mathrm{~kW}$ planar SOFC system for CHP application," Journal of Power Sources, vol. 131, no. 1-2, pp. 49-56, May 2004, doi: 10.1016/j.jpowsour.2004.01.025.

[30] Ro. Peters et al., "Operation Experience with a $20 \mathrm{~kW}$
SOFC System," Fuel Cells, vol. 14, no. 3, pp. 489-499, Jun. 2014, doi: 10.1002/fuce.201300184.

[31] R.-U. Dietrich, J. Oelze, A. Lindermeir, C. Spieker, C. Spitta, and M. Steffen, "Power Generation from Biogas using SOFC - Results for a $1 \mathrm{~kW}$ e Demonstration Unit," Fuel Cells, vol. 14, no. 2, pp. 239-250, Apr. 2014, doi: 10.1002/fuce.201300033.

[32] R. Nakashima, D. Flórez-Orrego, and S. de O. Junior, "Integrated anaerobic digestion and gasification processes for upgrade of ethanol biorefinery residues," Journal of Power Technologies, vol. 99, no. 2, pp. 104114, 2019.2 Available: https://papers.itc.pw.edu.pl/index.php/JPT/article/view/ 1475. [Accessed: May 10, 2021].

[33] R. N. Nakashima and S. de Oliveira Junior, "Comparative exergy assessment of vinasse disposal alternatives: Concentration, anaerobic digestion and fertirrigation," Renewable Energy, vol. 147, pp. 19691978, Mar. 2020, doi: 10.1016/j.renene.2019.09.124.

[34] F. Calise, M. Dentice d' Accadia, L. Vanoli, and M. R. von Spakovsky, "Single-level optimization of a hybrid SOFC-GT power plant," Journal of Power Sources, vol. 159, no. 2, pp. 1169-1185, Sep. 2006, doi: 10.1016/j.jpowsour.2005.11.108.

[35] K. W. Bedringås, I. S. Ertesvåg, S. Byggstøyl, and B. F. Magnussen, "Exergy analysis of solid-oxide fuel-cell (SOFC) systems," Energy, vol. 22, no. 4, pp. 403-412, Apr. 1997, doi: 10.1016/S0360-5442(96)00119-3.

[36] S. H. Chan, C. F. Low, and O. L. Ding, "Energy and exergy analysis of simple solid-oxide fuel-cell power systems," Journal of Power Sources, vol. 103, no. 2, pp. 188-200, Jan. 2002, doi: 10.1016/S03787753(01)00842-4.

[37] M. Gandiglio, A. Lanzini, P. Leone, M. Santarelli, and R. Borchiellini, "Thermoeconomic analysis of large solid oxide fuel cell plants: Atmospheric vs. pressurized performance," Energy, vol. 55, pp. 142-155, Jun. 2013, doi: 10.1016/j.energy.2013.03.059.

[38] Y. D. Lee, K. Y. Ahn, T. Morosuk, and G. Tsatsaronis, "Exergetic and exergoeconomic evaluation of a solidoxide fuel-cell-based combined heat and power generation system," Energy Conversion and Management, vol. 85, pp. 154-164, Sep. 2014, doi: 10.1016/j.enconman.2014.05.066.

[39] V. M. Janardhanan, V. Heuveline, and O. Deutschmann, "Performance analysis of a SOFC under direct internal reforming conditions," Journal of Power Sources, vol. 172, no. 1, pp. 296-307, Oct. 2007, doi: 10.1016/j.jpowsour.2007.07.008.

[40] D. D. Papadias, S. Ahmed, R. Kumar, and F. Joseck, "Hydrogen quality for fuel cell vehicles - A modeling study of the sensitivity of impurity content in hydrogen to the process variables in the SMR-PSA pathway," International Journal of Hydrogen Energy, vol. 34, no. 15, pp. 6021-6035, Aug. 2009, doi: 10.1016/j.ijhydene.2009.06.026. 